Article

\title{
Impact of Environmental Conditions and Agronomic Practices on the Prevalence of Fusarium Species Associated with Ear- and Stalk Rot in Maize
}

\author{
Annette Pfordt ${ }^{1, *}$, Lucia Ramos Romero ${ }^{1}$, Simon Schiwek ${ }^{2}$, Petr Karlovsky ${ }^{2}{ }^{\circledR}$ and \\ Andreas von Tiedemann ${ }^{1}$ \\ 1 Plant Pathology and Crop Protection, University of Goettingen, 37077 Goettingen, Germany \\ 2 Molecular Phytopathology and Mycotoxin Research, University of Goettingen, 37077 Goettingen, Germany \\ * Correspondence: annette.pfordt@uni-goettingen.de
}

Received: 6 March 2020; Accepted: 19 March 2020; Published: 21 March 2020

check for updates

\begin{abstract}
Fusarium species are common pathogens on maize and reduce the product quality through contamination with mycotoxins thus jeopardizing safety of both animal feed and human food products. Monitoring of Fusarium infected maize ears and stalks was conducted in Germany to determine the range of Fusarium species present in the field and to assess the impact of tillage, crop rotation, and weather conditions on the frequency of Fusarium species. From 2016 till 2018, a total of 387 infected ears and 190 stalk segments from 58 locations in Germany were collected. For each sample location, site-specific agronomic data on tillage and previous crops as well as meteorological data on precipitation, air temperature, and relative humidity during the vegetation period were recorded. The most frequent Fusarium species detected in maize ears were Fusarium graminearum, F. verticillioides and F. temperatum, whereas, F. graminearum, F. equiseti, F. culmorum, and F. temperatum were the species prevailing on maize stalks. Differences in the local species composition were found to be primarily associated with weather variations between the years and the microclimate at the different locations. The results indicate that mean temperature and precipitation in July, during flowering, has the strongest impact on the local range of Fusarium spp. on ears, whereas the incidence of Fusarium species on stalks is mostly affected by weather conditions during September. Ploughing significantly reduced the infection with F. graminearum and F. temperatum, while crop rotation exerted only minor effects.
\end{abstract}

Keywords: Fusarium spp., ear rot; stalk rot; maize; monitoring; weather conditions; agronomic practice

\section{Introduction}

Fusarium spp. in maize occur worldwide and can cause various diseases in different growth stages of maize, such as root and seedling rot as well as stalk and ear rot [1]. Fusarium ear rot (FER) and Fusarium stalk rot (FSR) are characterized by a white or reddish discoloration with rotting symptoms on the ears and inside the stalk [2,3]. Several toxigenic Fusarium species are known to cause yield losses, reduction of grain quality, thus endangering the safety of both animal feed and human food products $[4,5]$. The dominant Fusarium species causing ear and stalk rot in temperate climate zones are Fusarium graminearum, F. verticillioides, and F. subglutinans, producing numerous, chemically diverse mycotoxins, among which the most important are deoxynivalenol, zearalenon, and fumonisin [6,7].

Previous studies demonstrated, that the local Fusarium species composition is influenced by weather conditions as well as cultural practices [8-13]. Several routes are known by which the fungus may enter the kernels and the stalk including wounds by insects [14,15], silk infection and systemic spread after root penetration [1,16]. The major infection pathway for the infection of maize ears by 
most Fusarium species is via the silk channel with highest severity occurring at early stages of silk development $[17,18]$. In contrast, infection with F. verticillioides is often associated with injury by insects, primarily due to the feeding of the European corn borer (Ostrinia nubilalis), at 10-15 days after silk emergence. Stalk colonization has been reported to increase late in the season $[19,20]$ due to an increase in tissue susceptibility when carbohydrates and other nutrients are redirected towards developing kernels [21]. The importance of infection pathways and timepoints of infection may vary among geographical regions due to differences in weather conditions and the occurrence of insects. Temperature and moisture appear to be the most important factors affecting the range of Fusarium species of ear and stalk rot infection. Favorable weather conditions for an infection of Gibberella ear rot, mainly caused by F. graminearum and F. culmorum are low temperatures and high precipitation, whereas infection with F. verticillioides, F. subglutinans, and F. proliferatum (Fusarium ear rot) is promoted at high temperatures and dry conditions [22,23].

Likewise, cultural practices such as crop rotation and tillage have been reported to influence the disease incidence and severity of Fusarium infection in wheat and maize [24]. Residues of previous crops serve as source of inoculum for subsequent infection $[25,26]$ and also promote the survival of Ostrinia nubilalis, which may further enhance the risk of infection with Fusarium spp. [1,16]. Controversial effects of tillage and crop residues have been reported in previous studies. Some reports indicated no effect of alternating corn tillage practices on the incidence of ear rot pathogens [10,27-29], whereas others found a significant decrease in the diversity of Fusarium spp. in soil after conventional ploughing as compared to reduced tillage $[9,30,31]$.

Prevention of Fusarium infection focuses on cultural practices such as crop rotation and ploughing as well as improving host resistance. The success of these strategies has, however, been limited owing to the broad range of Fusarium species and large variation in host species and their genotypes. In addition, maize growing areas with short rotations of wheat and maize increased in recent years resulting in a higher risk of Fusarium ear and stalk infection and mycotoxin contamination [23,32]. The complex of Fusarium species may also have extended and shifted due to climate variations and more intense maize cultivation [33].

Therefore, the objective of this study was to determine the actual Fusarium species composition of maize fields in Germany and to estimate how the frequency of local Fusarium species is affected by cultural practices (tillage and previous crop) and weather conditions (air temperature and precipitation) under natural infection from 2016 to 2018.

\section{Results}

\subsection{Fusarium Species Involved in Ear and Stalk Infections}

In the three years of field investigations, a total number of 11,610 kernels and 3483 rachis and stalk samples were analyzed to determine the local Fusarium spp. composition. In the years 2017 and 2018, twelve Fusarium species were identified. In 2016, F. verticillioides and F. proliferatum as well as F. temperatum and F. subglutinans were treated as a species complex of F. proliferatum sp. and $F$. subglutinans sp., respectively (Table 1 ).

In 2016 and 2017, F. graminearum was the predominant species in maize ears and detected in over $60 \%$ of all tested samples. The detection frequency of $F$. graminearum differed from year to year, with $79 \%$ in 2016, 71\% in 2017 and 30\% in 2018. F. verticillioides was the prevailing species in 2018 and detected in $39 \%$ of all ears. In total, F. verticillioides colonized $24 \%$ of all tested ears from 38 locations. Detection frequency of $F$. temperatum ranged from $15 \%$ in 2017 up to $33 \%$ in 2016 . In total, $23 \%$ of all ears analyzed were infected with F. temperatum. F. poae colonized $14 \%$ of all tested ears followed by minor species such as F. cerealis (9\%), F. proliferatum (6\%), F. tricinctum (5\%), F. avenaceum (5\%), F. culmorum $(4 \%)$, F. subglutinans ( $2 \%)$, F. equiseti $(2 \%)$, and F. sporotrichioides $(2 \%)$. Similar to ears, F. graminearum was also prevailing on maize stalks where; it was detected in $62 \%$ of all tested samples. In 2017, F. graminearum was present in more than $80 \%$ of the stalks and occurred at almost each sampling 
location. F. equiseti colonized a total of $22 \%$ of the samples within two years of investigation, however, the percentage of infected stalks containing F. equiseti was much higher in 2018 (34\%) compared to 2017 (11\%). F. culmorum was the third most frequent species isolated from $22 \%$ of the stalks in 2017 and $16 \%$ in 2018. Infection with F. temperatum and F. cerealis was found in $17 \%$ of the stalk samples, however, F. cerealis was more frequent in 2017 (19\%) and F. temperatum in $2018(20 \%)$. F. verticillioides, F. avenaceum, F. tricinctum, F. poae F. subglutinans, and F. sporotrichioides were detected less frequently.

Table 1. Percentage of ears and stalks infected with Fusarium species.

\begin{tabular}{|c|c|c|c|c|c|c|c|c|c|c|c|c|c|}
\hline \multirow[b]{3}{*}{ Fusarium Species } & \multicolumn{7}{|c|}{ Ears Infection } & \multicolumn{6}{|c|}{ Stalk Infection } \\
\hline & \multicolumn{4}{|c|}{ Frequency [\%] } & \multicolumn{3}{|c|}{ Sample Sites } & \multirow[b]{2}{*}{ Fusarium Species } & \multicolumn{3}{|c|}{ Frequency [\%] } & \multicolumn{2}{|c|}{ Sample Sites } \\
\hline & 2016 & 2017 & 2018 & Total & 2016 & 2017 & 2018 & & 2017 & 2018 & Total & 2017 & 2018 \\
\hline F. gramineaum & 79 & 71 & 30 & 60 & 17 & 41 & 15 & F. graminearum & 81 & 43 & 62 & 20 & 11 \\
\hline F. verticillioides & $19^{2}$ & 13 & 39 & 24 & 11 & 11 & 16 & F. equiseti & 11 & 34 & 22 & 10 & 9 \\
\hline F. temperatum & $33^{1}$ & 15 & 21 & 23 & 11 & 21 & 15 & F. culmorum & 22 & 16 & 19 & 14 & 11 \\
\hline F. tricinctum & 4 & 7 & 2 & 5 & 3 & 8 & 3 & F. avenaceum & 6 & 5 & 5 & 5 & 3 \\
\hline F. avenaceum & 10 & 5 & 1 & 5 & 4 & 8 & 1 & F. tricinctum & 5 & 8 & 6 & 4 & 5 \\
\hline F. culmorum & 1 & 5 & 4 & 4 & 1 & 9 & 3 & F. proliferatum & 3 & 11 & 6 & 3 & 5 \\
\hline \multirow[t]{2}{*}{ F. subglutinans } & * & 2 & 2 & 2 & * & 3 & 3 & F. poae & 3 & 5 & 4 & 3 & 3 \\
\hline & & & & & & & & F. subglutinans & 1 & 3 & 2 & 1 & 2 \\
\hline F. sporotrichoides & 4 & 1 & 5 & 2 & 3 & 1 & 4 & F. sporotrichoides & 1 & 0 & 1 & 1 & 0 \\
\hline
\end{tabular}

${ }^{1}$ In 2016, there was no differentiation between $F$. subglutinans and F. temperatum. ${ }^{2}$ In 2016, there was no differentiation between F. verticillioides and F. proliferatum.

\subsection{Effect of Previous Crop}

The abundance of the three most frequent species on ears (F. graminearum, F. verticillioides, and F. temperatum) and the four species prevailing on stalks (F. graminearum, F. equiseti, F. culmorum, and F. temperatum) after different pre-crops is shown in Figure 1. Crop rotation had no significant effect on ear and stalk infection with F. graminearum, F. temperatum, F. equiseti, and F. culmorum. The frequency of $F$. graminearum on ears was slightly reduced in maize after maize as compared to wheat, sugar beet and non-host crops like potato, strawberries or cabbage. The highest frequency of stalk infection with F. graminearum was observed on maize after other crops, followed by wheat, maize and sugar beet. No effects of pre-crops were found for ears infected with F. temperatum. Maize as previous crop slightly favored stalk infection with $F$. equiseti $(30 \%)$ while colonization with F. culmorum was slightly increased after wheat (27\%). Only F. verticillioides indicated strong differences in frequency of ear infection. Colonization of $F$. verticillioides was significantly favored by maize after maize in comparison to maize after sugar beet. 


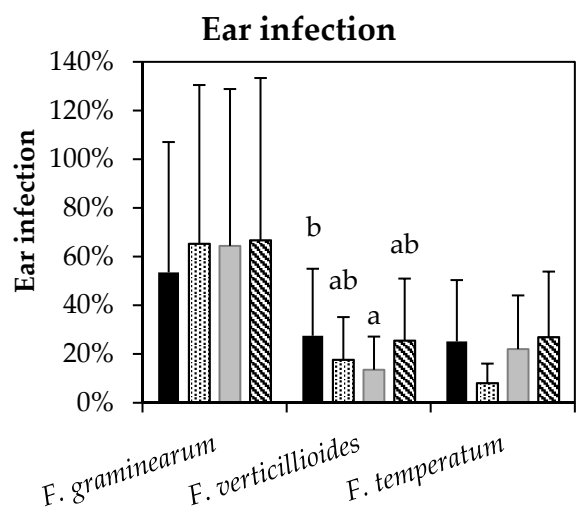

- Maize : Wheat $\square$ Sugar beet $\mathbb{\text { Nother }}$

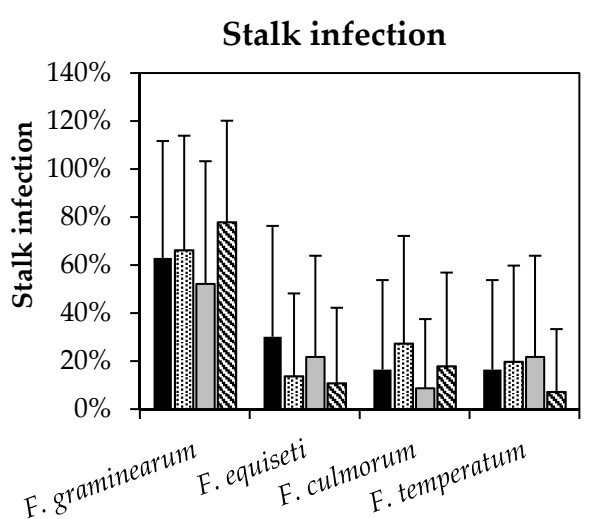

- Maize 国 Wheat $\square$ Sugar beet $\mathbb{Q}$ others

(b)

Figure 1. Percentage of ears (a) infected with F. graminearum, F. verticillioides, and F. temperatum and stalks (b) infected with F. graminearum, F. equiseti, F. culmorum, and F. temperatum depending on the previous crop (maize, wheat, sugar beet, others). Vertical bars represent standard deviations. Different letters indicate significant differences $(p \leq 0.05)$ within species.

\subsection{Effect of Tillage}

Ear and stalk infection with F. graminearum, F. verticillioides, and F. equiseti were significantly affected by the type of soil tillage as shown in Figure 2. Apart from F. verticillioides and F. equiseti, reduced tillage (chisel ploughing and rotary harrow) favored infection with most Fusarium species compared to moldboard ploughing. Hence, colonization with F. graminearum in ear and stalk samples was significantly higher at reduced tillage compared to moldboard ploughing. Similarly, ear infection with $F$. temperatum was reduced after ploughing $(30 \%)$ compared to reduced tillage $(17 \%)$. Ploughing also reduced the frequency of Fusarium species in maize stalks, however, it led to higher frequencies in observations with F. equiseti. The percentage of ears colonized with $F$. verticillioides was significantly higher after ploughing (24\%) than after reduced tillage (12\%). F. equiseti was equally favored by ploughing $(28 \%)$ as compared to reduced tillage $(7 \%)$. The type of tillage had no significant effect on stalk infection with F. culmorum and F. temperatum.

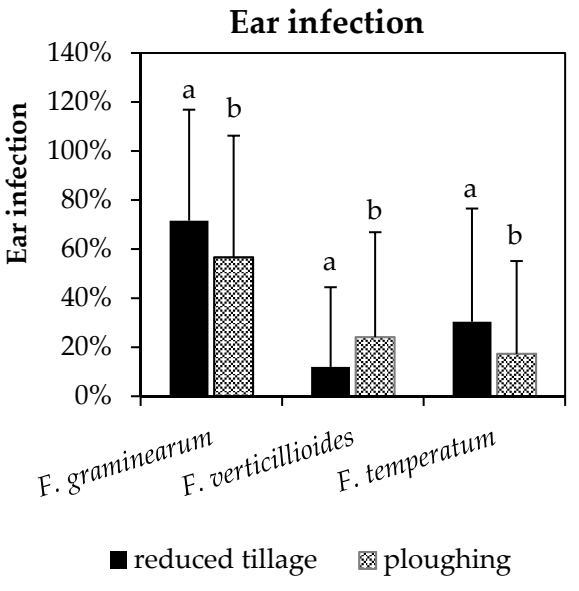

(a)

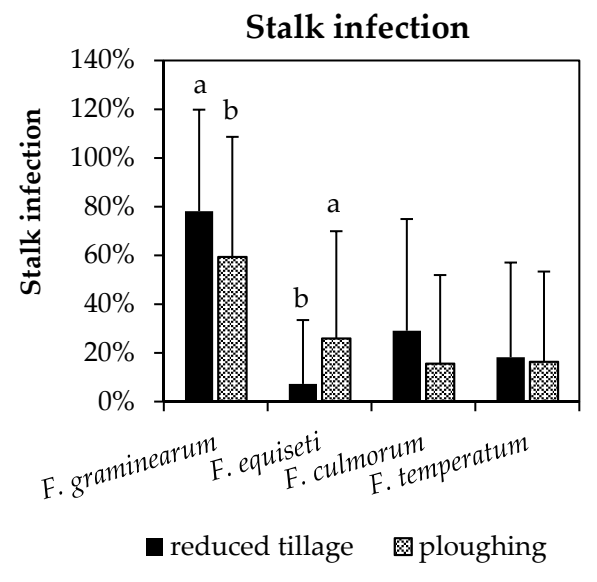

(b)

Figure 2. Percentage of ears (a) infected with F. graminearum, F. verticillioides, and F. temperatum and stalk (b) infected with F. graminearum, F. equiseti, F. culmorum, and F. temperatum depending on tillage (reduced tillage vs. ploughing). Vertical bars represent standard deviation. Different letters indicate significant differences $(p \leq 0.05)$ within species. 


\subsection{Effect of Environmental Conditions}

The relationship between the frequency of Fusarium species on ears (F. graminearum, F. verticillioides, and F. temperatum) and stalks (F. graminearum, F. equiseti, F. culmorum, and F. temperatum) and weather conditions after flowering was analyzed using Pearson correlation (Supplementary Table S1). While temperature and precipitation in June had no significant effect on the occurrence of the most frequent Fusarium species (Figure 3), temperature and precipitation during flowering in July had a medium to strong effect on the frequency of the prevailing species. Colonization of $F$. graminearum negatively correlated $(\mathrm{r}=-0.42)$ with temperature in July and positively correlated $(\mathrm{r}=0.70)$ with precipitation in July. F. temperatum was favored by low precipitation $(\mathrm{r}=-0.71)$ and F. verticillioides was found to be more frequent at high temperatures $(r=0.69)$ and low precipitation $(r=-0.71)$. Temperature and precipitation during August and September had minor effects on frequencies of Fusarium species. The correlations described above demonstrate the critical impact of temperature and precipitation in July on ear infection with the most frequent Fusarium species (Figure 4). Frequency of F. graminearum was inversely related to temperature $(\mathrm{r}=-0.42)$ and positively correlated with precipitation in July $(r=-0.71)$. Ear infection with $F$. verticillioides significantly increased with temperature $(r=0.67)$ and low precipitation $(\mathrm{r}=0.72)$. The temperature in July had no effect on colonization with $F$. temperatum, however, dry conditions promoted $\left(\mathrm{r}^{2}=-0.57\right)$ infections of the ear.

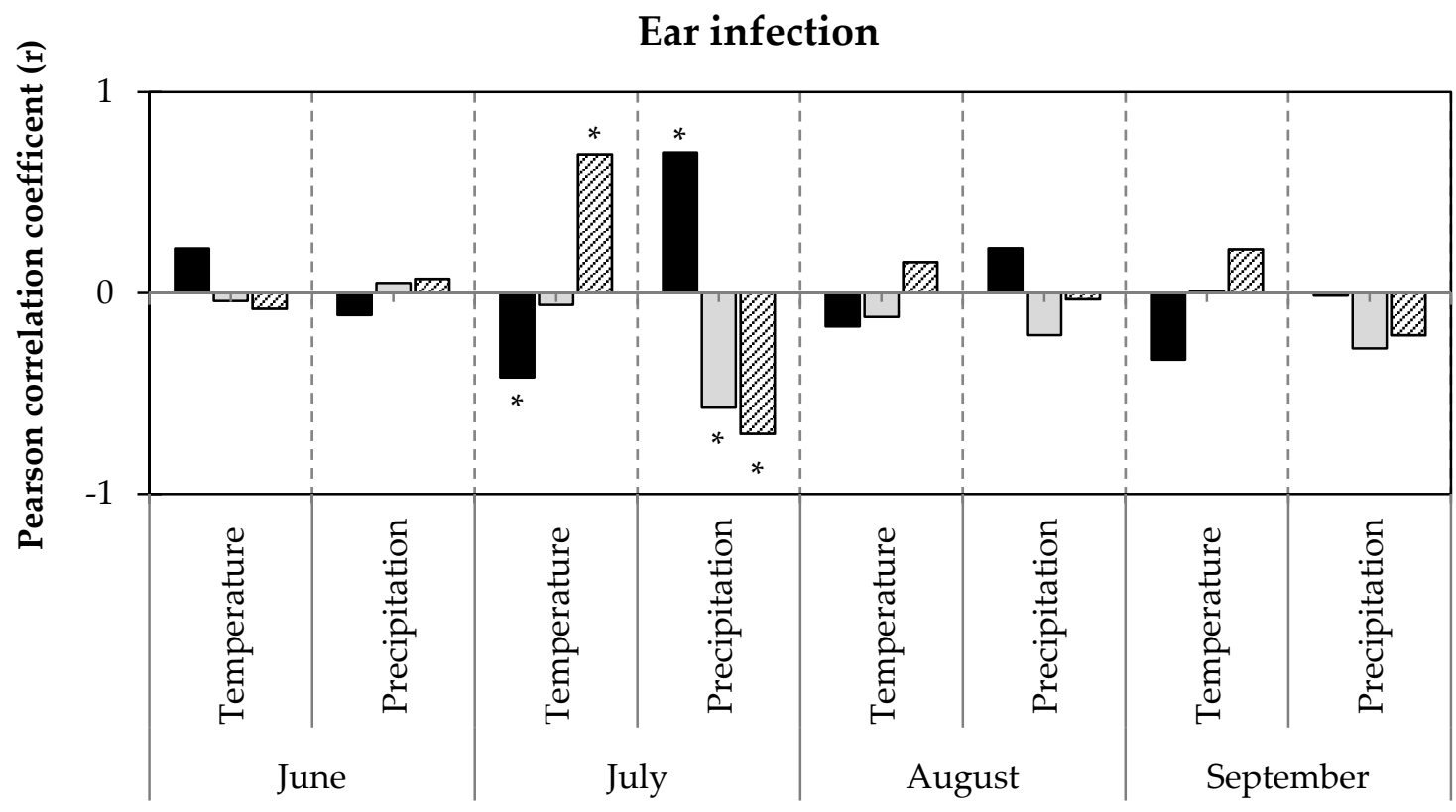

F. graminearum $\square$ F. temperatum $\square$ F. verticillioides

Figure 3. Coefficients of correlation of temperature and precipitation during June, July, August, and September with ear infection by F. graminearum, F. temperatum and F. verticillioides. Bars represent coefficients of correlation between percentage of sampled ears per location infected with F. graminearum, F. temperatum, and F. verticillioides and weather data at the sampling sites recorded in 2016, 2017 and $2018(\mathrm{n}=387)$. Asterisk $\left(^{*}\right)$ indicates statistically significant correlation $(p \leq 0.05)$. 
F. graminearum

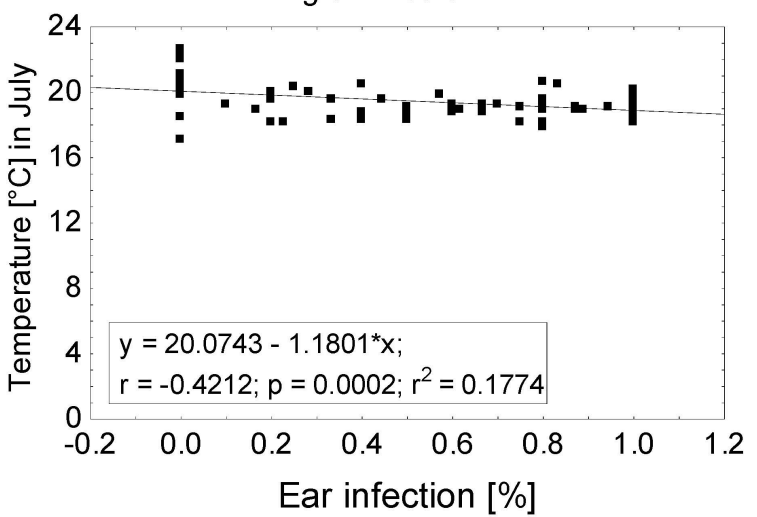

F. verticillioides

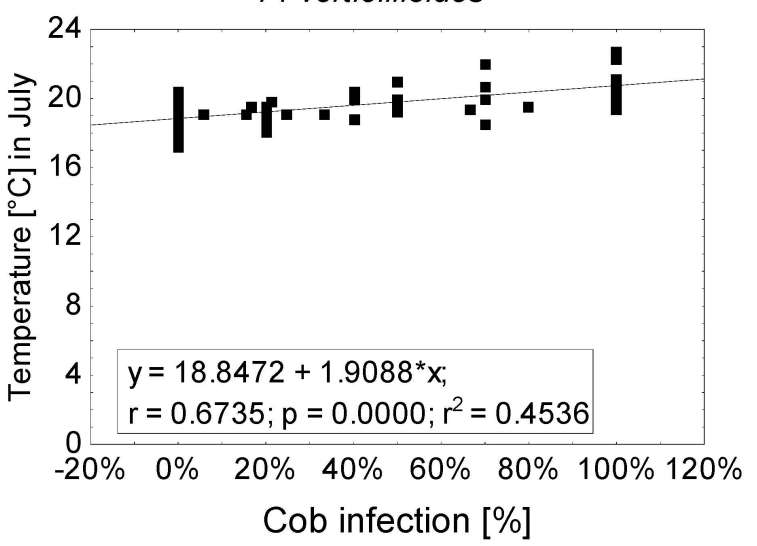

F. temperatum

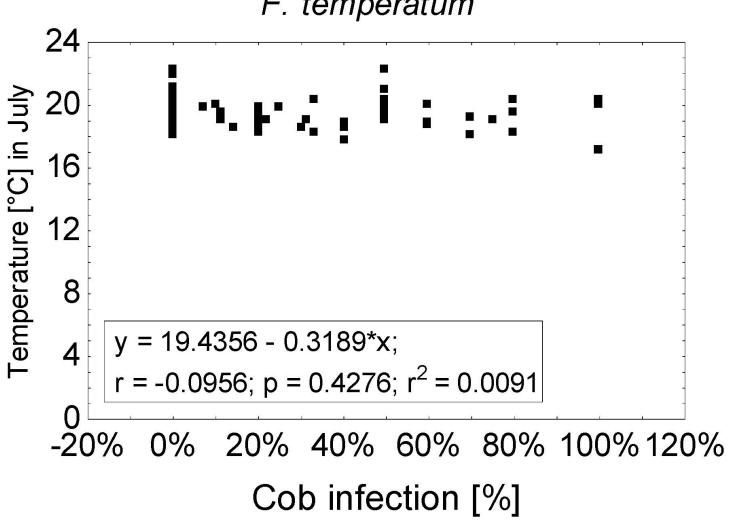

(a)
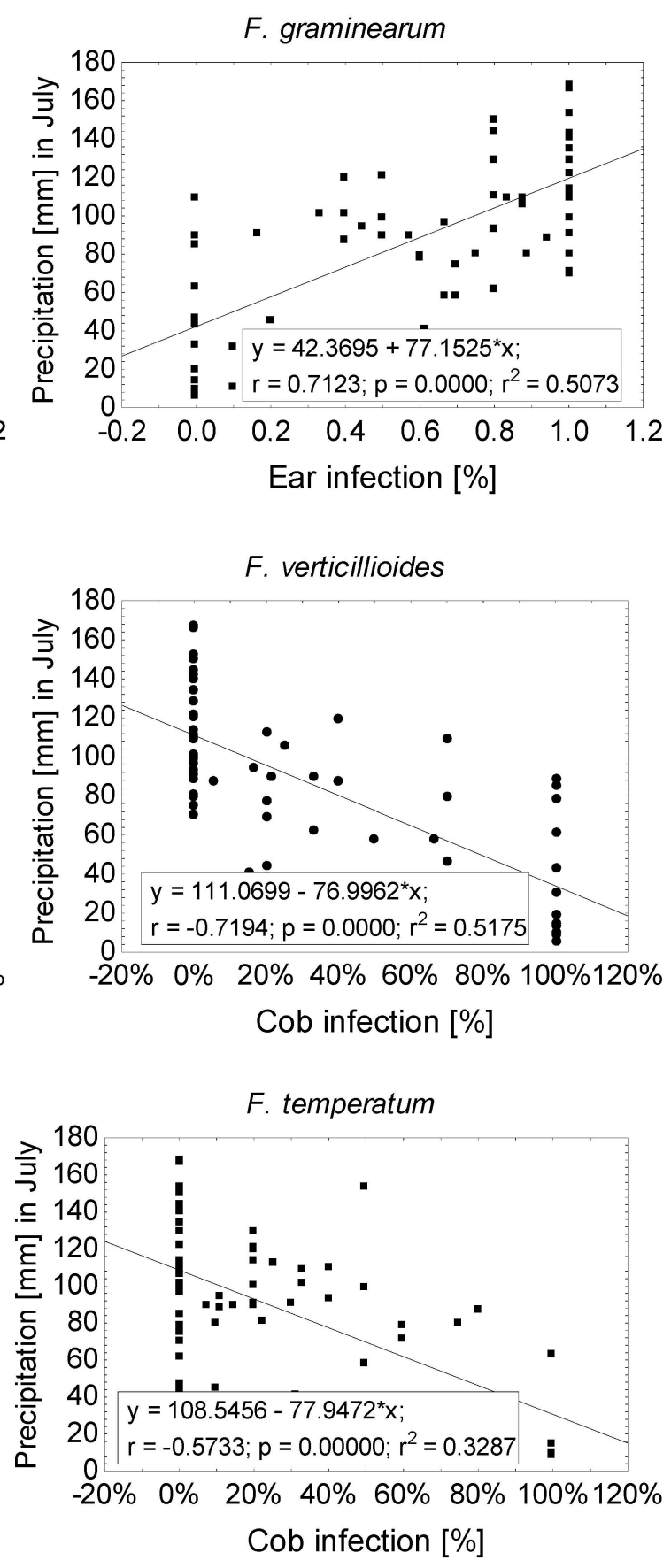

(b)

Figure 4. Relationship between ear infection [\%] and temperature (a) or precipitation (b) in July of F. graminearum, F. equiseti, F. culmorum, and F. temperatum. Solid line indicates a statistically significant $(p \leq 0.05)$ least squares linear relationship.

In contrast to ear infection, the abundance of the most frequent Fusarium species on stalks (F. graminearum, F. equiseti, F. culmorum, and F. temperatum) displayed significant correlation with temperature and precipitation during the month of September (Figure 5). F. graminearum was significantly enhanced at low temperature $(\mathrm{r}=0.38)$ and low precipitation $(\mathrm{r}=-0.54)$. However, F. temperatum $(\mathrm{r}=0.63)$ and F. culmorum $(\mathrm{r}=0.46)$ were favored by high temperature. Temperature and precipitation had no effect on the frequency of stalk infection with $F$. equiseti. The specific relationship between temperature and precipitation in September on one hand and stalk infection with the most 
frequent Fusarium species on the other hand (Figure 6) revealed increased frequency of $F$. graminearum at low temperatures $(\mathrm{r}=-0.38)$ and dry conditions $(\mathrm{r}=-0.54)$. In turn, the percentage of ears infected with F. temperatum $(\mathrm{r}=0.70)$ and F. culmorum $(\mathrm{r}=0.46)$ increased at higher temperatures. Precipitation in September had no effect on stalk infection neither with F. temperatum nor F. culmorum. Stalk infection with F. equiseti was not influenced by temperature or precipitation during ripening.

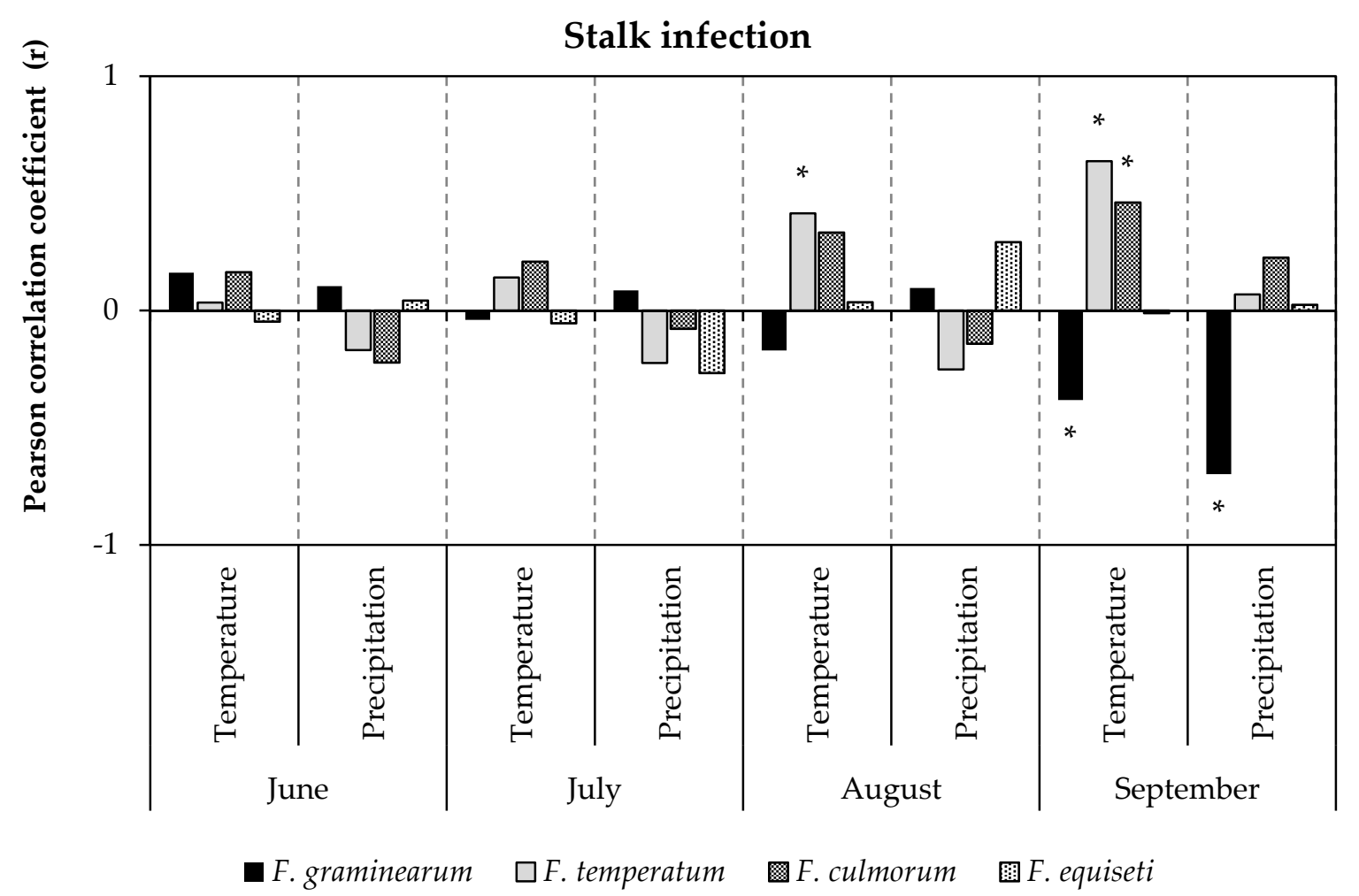

Figure 5. Coefficients of correlation of temperature and precipitation during June, July, August, and September with stalk infection by F. graminearum, F. temperatum, F. culmorum, and F. equiseti. Bars represent coefficients of correlation between percentage of stalks sampled per location infected with F. graminearum, F. temperatum, F. culmorum, and F. equiseti and weather data recorded at the sampling sites in 2017 and $2018(n=190)$. Asterisk $\left({ }^{*}\right)$ indicates statistically significant $(p \leq 0.05)$ correlation. 

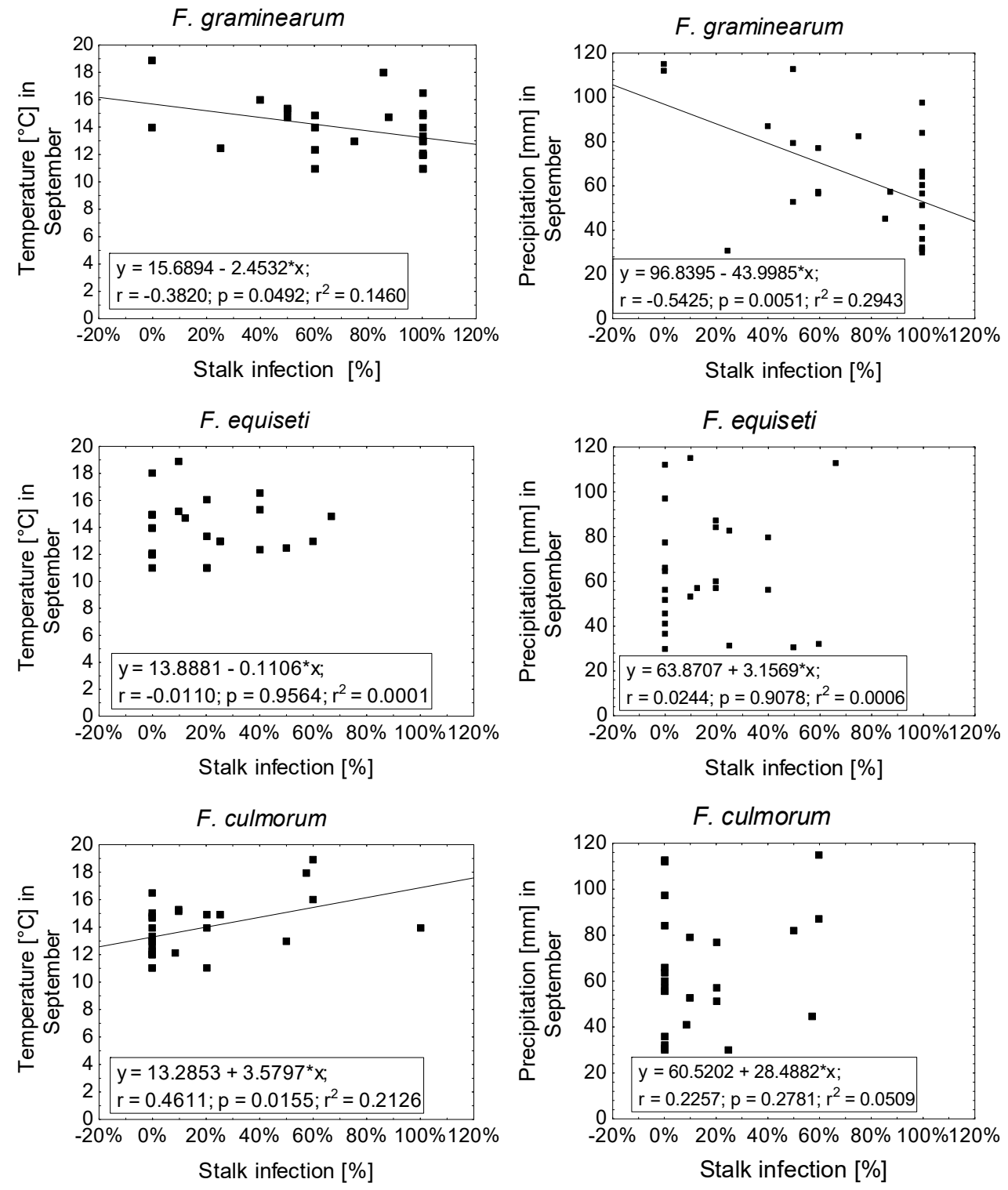

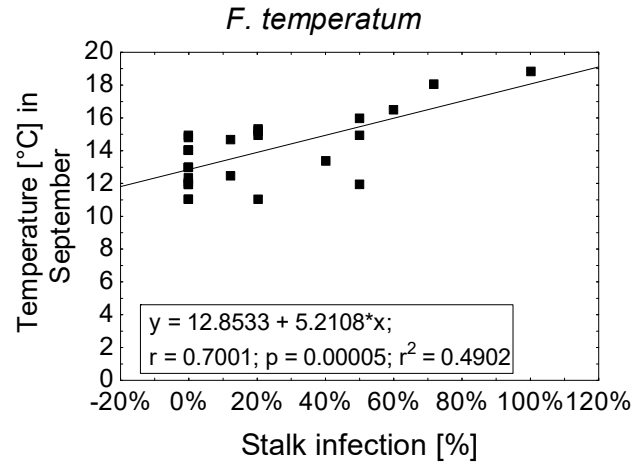

(a)

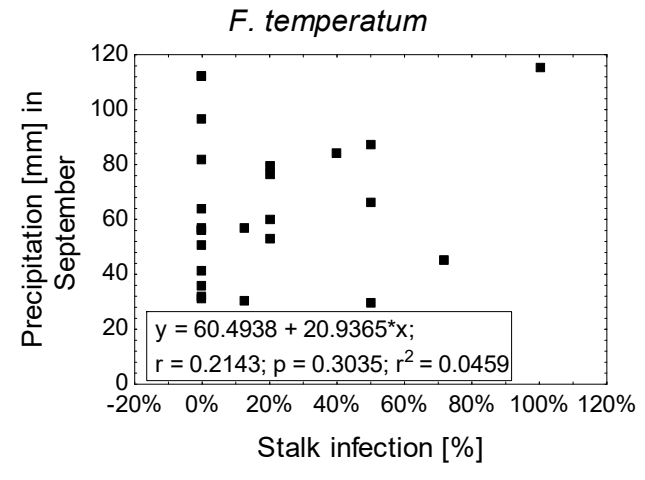

(b)

Figure 6. Relationship between stalk infection [\%] with F. graminearum, F. equiseti, F. culmorum, and F. temperatum and temperature (a) or precipitation (b) in September. Solid lines indicate a statistically significant $(p \leq 0.05)$ least squares linear relationship. 


\subsection{Relative Impact of Main Effects}

The effects of tillage, previous crop, year and location on the percentage of ears and stalks infected with the most frequent Fusarium species were compared using the variance components of each factor (Figure 7). The strongest effect was found for the sampling location, which affected the infection of maize ears with F. graminearum (34.9\% of variance), F. verticillioides (26.3\%), and F. temperatum $(28.5 \%)$. Furthermore, the frequency of $F$. graminearum was influenced by the year of sampling (24\%), less by the type of tillage (3.9\%) and the previous crop (1\%). Similarly, the occurrence of $F$. verticillioides and F. temperatum were most strongly determined by the location, followed by year, previous crop and tillage. Tillage and previous crop had minor effects on ear colonization with any of the tested Fusarium species.

Stalk infection with F. graminearum, F. equiseti, F. culmorum, and F. temperatum was mainly affected by the year and location. Stalk infection with F. graminearum $(26.3 \%)$ strongly differed between the years, while stalk infection with F. equiseti $(27.1 \%)$, F. culmorum (26.4\%), and F. temperatum $(11.8 \%)$ was mainly affected by the location. The previous crop had almost no effect on Fusarium species composition and tillage only slightly influenced the colonization with F. graminearum (6.2\%), F. equiseti (8.9\%), and F. culmorum (4.4\%).

\section{Ear infection}

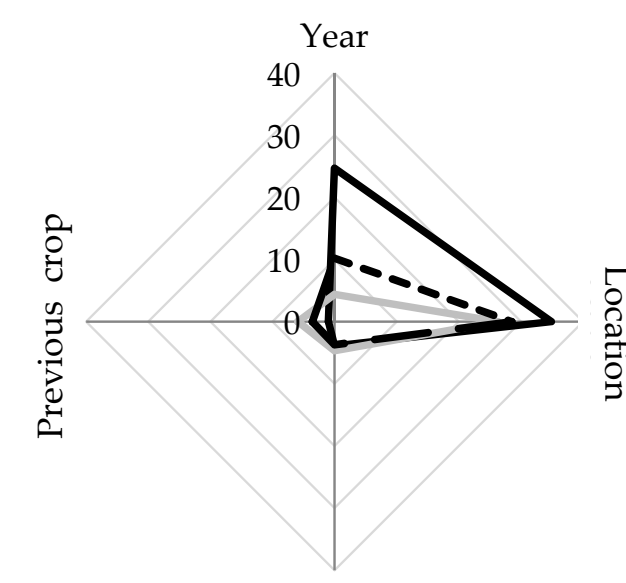

Tillage

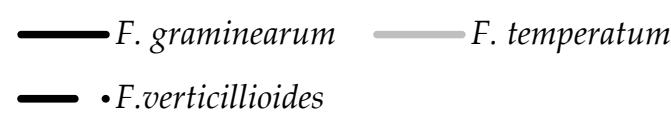

(a)

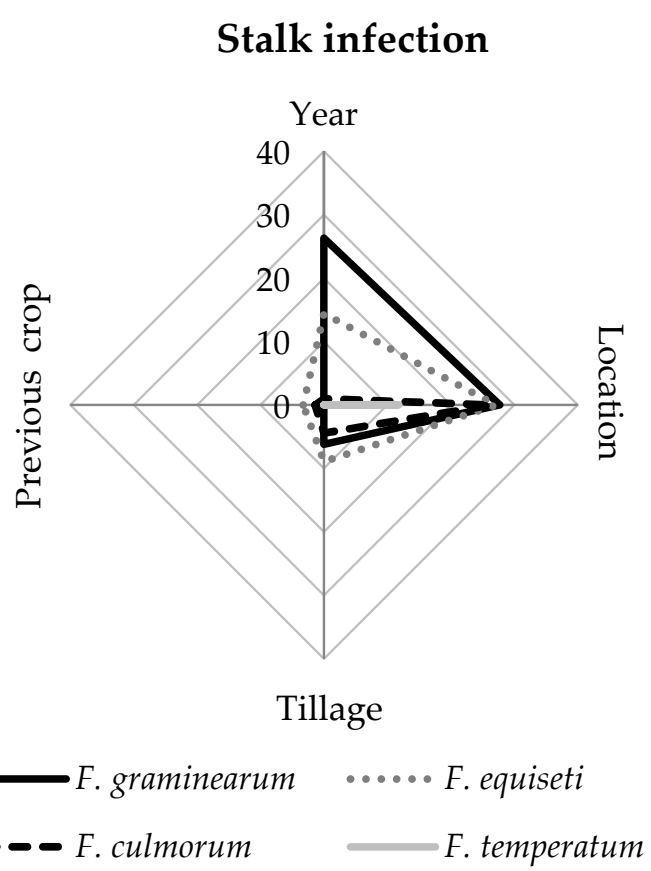

(b)

Figure 7. Relative impact of main effects (year, location, tillage, previous crop) expressed as percentage of variance of the total variance estimated with the restricted maximum likelihood model. Ear infection (a) calculated for F. graminearum, F. temperatum, and F. verticillioides. Stalk infection (b) calculated for F. graminearum, F. equiseti, F. culmorum, and F. temperatum.

\section{Discussion}

Within the three years of investigations of maize ears and stalks, twelve Fusarium species were isolated and identified. All the species detected are known to frequently occur on maize ears and stalks in Central Europe [34]. High year to year variability was observed for the frequency of Fusarium spp., which indicated a major impact of temperature and precipitation during the vegetation period. The growing seasons in 2016 and 2017 were characterized by moderate temperatures $\left(18.8^{\circ} \mathrm{C}\right)$ and high precipitation in July $(110 \mathrm{~mm})$, while in 2018 high mean temperatures $\left(20.6^{\circ} \mathrm{C}\right)$ and dry conditions ( $40 \mathrm{~mm}$ in July) prevailed. This might explain the high frequency of F. graminearum and F. culmorum in 
2016 and 2017 when more than $70 \%$ of all tested ears and $80 \%$ of all tested stalks were colonized with these two species. In contrast, $F$. verticillioides was the prevailing species in 2018 , colonizing almost $40 \%$ of all ears analyzed.

Numerous studies confirm that moderate temperature and high level of moisture increases infection rates of F. graminearum, F. culmorum, and F. avenaceum (Gibberella ear rot) [22,25,35], while Pink ear rot pathogens such as F. verticillioides, F. proliferatum, and F. temperatum have often been reported from southern European regions where dry and warm conditions prevail [36]. These patterns correspond to different temperature optima of the species. The optimal growth rate for F. graminearum was reported 24-26 ${ }^{\circ} \mathrm{C}$ [37] and high level of moisture, whereas optimal conditions of $F$. verticillioides are $30^{\circ} \mathrm{C}$ and 0.97 water activity $[2,38]$. The primary infection pathway for ear infection is via the silk channel (during the first 6 to 10 days after silk emergence) or insect injury of kernels (during grain filling). Under mid European conditions, silk emergence takes place between beginning of July and mid-July. At this time, weather conditions as well as insect populations strongly affect Fusarium spp. infection $[1,16]$. Gibberella ear rot pathogens are favored by high levels of moisture during silking, followed by moderate temperatures and high precipitation during cob maturation [25]. Shelby et al. [39] demonstrated that fumonisin levels and the occurrence of Fusarium ear rot pathogens were inversely correlated with rainfall in June and July. In particular, drought stress is associated with an elevated infection with $F$. verticillioides [40]. The present study confirmed that a dry period with high temperatures before and during grain filling favors ear infection with $F$. verticillioides and $F$. temperatum, while the frequency of $F$. graminearum was higher at lower temperatures and high precipitation. While temperature, precipitation and relative humidity during flowering were incorporated into forecasting models for Fusarium head blight on wheat [41], available risk assessment models for Fusarium ear rot disease were not sufficiently detailed to maize and cannot be extrapolated from the existing risk assessment models for Fusarium head blight [42]. Only Stewart et al. [43] were able to develop a mechanistic model relating the growth rates of $F$. graminearum and F. verticillioides to temperature, relative humidity, and precipitation which effectively predicted ear rot severity after artificial inoculation.

In contrast to ear infection, stalk infection was mainly influenced by temperature during ripening in August and September. Fusarium species can enter the stalk during the whole vegetation period by systemic spread after colonization of the root [1,44], through young leaf sheaths, by seed transmission [45] and via wounds caused by hail or feeding of insects [3]. Consequently, stalk rot infection is not restricted to a specific time point and fungal infection does not correlate with seasonal weather conditions. However, temperature substantially affected the extent of invasion of Fusarium pathogens during ripening [30,44]. Murillo-Williams and Munkvold [44] suggested that higher temperatures in particular lead to faster maturity of the plants promoting systemic infections of species which are adapted to warmer temperature such as F. verticillioides. Stalk rot usually occurs at physiological maturity, in August and September, when storage products in stalks are depleted and most carbohydrates are translocated to the cob [46]. Accordingly, Dodd [21] reported that at maturity stages the root and lower stalk tissues lose their metabolic activity and thus their defense potential against stalk infection. In addition, further stresses such as drought, high plant density, leaf diseases, and corn borer attacks may also favor stalk rot due to decreasing photosynthesis rate [21]. F. temperatum, a species recently separated from $F$. subglutinans based on its phylogeny and mycotoxin production, colonized up to $20 \%$ of all analyzed ear and stalk samples. The frequency of $F$. subglutinans within the three years of investigation was low (2\%); F. subglutinans therefore played only a minor role in ear and stalk infection. A higher incidence of $F$. temperatum in comparison to $F$. subglutinans was also reported from maize in Belgium [47], Poland [48], France [49], and Italy [50] as well as North America [51], Korea, [52], China [53], Mexico [54], and Argentina [55]. The data of the present study demonstrate that kernel colonization with $F$. temperatum was significantly favored by low precipitation during flowering in 2018. Moretti et al. [56] suggested that isolates belonging to group 1 (F. temperatum) are more frequent in cooler regions like Germany, Poland and Austria while group 2 (F. subglutinans) prevails in warmer and dryer regions such as Slovakia, Italy and Serbia. Czembor et al. [48] reported a 
similar trend of $F$. temperatum occurring more often in environments with mean temperatures of $18^{\circ} \mathrm{C}$ or lower in June, like in Germany.

In the present study, only low or no impact of crop rotation on ear and stalk infection with Fusarium spp. was observed. These findings correspond with the results from investigations by Dill-Macky and Jones [24] and Schaafsma et al. [57] indicating that similarly high disease levels caused by $F$. graminearum are found in maize grown after maize and wheat, compared to sugar beet and other pre-crops like rape seed, potato, or strawberries. A similar tendency was observed by Schlüter and Kropf [29] and Gödecke [58], who reported a high disease incidence by F. culmorum and F. graminearum on wheat after non-host crops like oilseed rape and sugar beet. Mansfield et al. [9] also reported no effect of crop rotation with broadleaf crops on DON contamination of maize stalks. The most important source of inoculum for Fusarium spp. are plant debris, especially maize stalks. However, these fungi are also pathogenic in cereals such as wheat, barley, oats and rye as well as sugar beet. Fusarium spp. can survive as mycelium and other structures on residues of these crops as well as on senescent tissue of other crops or weed species, which may later serve as primary inoculum for infection [59]. Resting structures such as chlamydospores and thick-walled hyphae can survive up to ten years breaks between host crops on plant residues buried at $30 \mathrm{~cm}$ depth or left on the soil surface $[25,60]$. Long-term survival studies by Cotton and Munkvold [26] indicate an equal survival of Fusarium species in buried residues and surface residues after 343 days and suggest that surface residues may act as a reservoir of recolonization and spore production for airborne inoculum and spread into the next vegetation period.

Therefore, management of surface residues by tillage and deep burial are suggested as an important strategy to control ear and stalk rot diseases [61]. The results of this study indicate that, the incidence of local Fusarium species on ears and stalks is highly affected by conventional ploughing compared to chisel ploughing or no tillage. In particular, the frequency of F. graminearum, F. temperatum, and F. culmorum was reduced after conventional ploughing, however, F. verticillioides and F. equiseti were enhanced by ploughing. Our study confirms the results reported by Dill-Macky and Jones [24] and Steinkellner and Langer [62], which demonstrated that most Fusarium species were reduced after moldboard ploughing as compared to reduced tillage. Covering crop residues with soil accelerates their decomposition by enhancing microbial activity and this reduces inoculum density $[63,64]$. However, investigations by Byrnes and Carroll [65] confirmed higher severity of $F$. equiseti infection after conventional tillage, whereas the concentration of DON produced by F. graminearum and the population density of $F$. subglutinans were reduced by conventional tillage $[11,13,30]$. Steinkellner and Langer [62] emphasized that ploughing compared to chisel plough and rotary tiller treatments reduced the number of colony forming units (CFU) per g of soil and the frequency of Fusarium species in upper soil layers. However, Fusarium species composition differed between different soil layers due to different survival structures of the species [31]. Especially $F$. verticillioides survived best in maize stalks at $30 \mathrm{~cm}$ depth due to higher moisture content and poor decomposition of plant tissue [60]. According to this study and previous research, weather conditions had the largest influence on the local Fusarium species composition and disease incidence in maize, however, prevention and management practices including crop rotation and tillage types may also affect ear and stalk rot diseases and mycotoxin accumulation $[2,9,12,66,67]$.

In the three years of investigation (2016-2018), F. graminearum, F. verticillioides and F. temperatum were the most frequent Fusarium species on maize in Germany. A high year-to-year variability was observed in the shift of species composition towards a high occurrence of $F$. verticillioides. Increasing temperatures and dry periods in summer can affect the Fusarium species complex and increase the risk of contamination with fumonisin-producing species such as F. verticillioides and F. temperatum [48]. In addition, feeding of the European corn borer (Ostrinia nubilalis) and the Western corn rootworm (Diabrotica virgifera) in Germany will likely further enhance disease incidence and mycotoxin contamination of ears and stalks as well as root rots in maize $[11,16,68]$. The current expansion of maize acreage and shorter crop rotations with other small grain cereals due to renewable energy policy will further increase the risk of Fusarium infection and mycotoxin contamination. 
The current results emphasize the importance of further studies of the impact of changing climatic conditions and its interplay with cultural practices on the development of Fusarium population and the mycotoxin contamination of maize crops.

\section{Materials and Methods}

\subsection{Sampling and Isolation}

Naturally Fusarium-infected maize ear and stalk samples were collected from silage and grain maize fields in Germany in 2016 (94 ears from 18 locations), 2017 (180 ears from 42 locations and 110 stalks from 21 locations) and 2018 (113 ears from 18 locations and 80 stalks from 14 locations). For each sample site agronomic data like soil tillage and previous crop as well as meteorological data such as precipitation, air temperature, and humidity during the vegetation period were recorded. Five to nine Fusarium-infected ears or stalks per location were placed in paper bags and sent to the Plant Pathology and Plant Protection Division in Göttingen, Germany for further analysis. Disease severity on kernels and rachis was scored according to EPPO Guidelines [69].

Thirty randomly chosen kernels of each ears were surface sterilized for $10 \mathrm{~min}$ with $0.1 \%$ silver nitrate and incubated on moist sterile filter paper for two days at room temperature. Afterwards, kernels with outgrowing Fusarium mycelium were placed on potato dextrose agar (PDA). The rachis was cut in nine slices, three from the base, three from the middle part and three from the tip of the ears. The slices were surface sterilized as described above and placed directly on PDA plates. The stalk samples were cut in nine slices, three from the lower nodium, three from the internodium and three from the upper nodium. The samples were surface sterilized and placed on PDA plates as the rachis slices. After two days, presumed Fusarium mycelium outgrown from the samples was transferred to synthetic low nutrition agar (SNA) to produce single spore cultures. The isolates were stored as single spore cultures on synthetic SNA plates at $4{ }^{\circ} \mathrm{C}$.

The ear and stalk infection were calculated by the following equation:

$$
\begin{gathered}
\text { Ear infection }[\%]=\frac{\begin{array}{c}
\text { Number of Fusarium } \\
\text { infected kernels per cob }
\end{array}}{\begin{array}{c}
\text { Number of kernels } \\
(\mathrm{n}=30)
\end{array}} \div \text { Cobs per location } \\
\text { Stalk infection }[\%]=\frac{\begin{array}{c}
\text { Number of Fusarium } \\
\text { infected slices per stalk }
\end{array}}{\text { Number of slices }}(\mathrm{n}=9)
\end{gathered} \text { Stalks per location }
$$

\subsection{Species Identification}

In vitro cultures of Fusarium were identified macroscopically by colony characters on PDA and microscopically on SNA [70]. Total DNA was extracted from lyophilized mycelium from single spore cultures by using a CTAB-based protocol as described previously [71]. Standards of genomic DNA were obtained from F. temperatum MUCL52463 and F. subglutinans CBS215.76 [45]. The quality and quantity of extracted DNA were assessed after electrophoretic separation in agarose gels $(0.8 \%(\mathrm{w} / \mathrm{v})$ stained with ethidium bromide. The electrophoresis was carried out for $60 \mathrm{~min}$ at $4.6 \mathrm{~V} / \mathrm{cm}$.

Partial translation elongation factor 1-alfa (tef1 $\alpha$ ) nucleotide sequence was used to differentiate between $F$. temperatum and F. subglutinans. Amplification was performed in a peqSTAR96 thermocycler (PEQLAB, Erlangen, Germany) using 1:100 dilutions of DNA extracts in a total reaction volume of $25 \mu \mathrm{L}$.

The tef1 $\alpha$ gene was amplified using primers EF1 (ATGGGTAAGGARGACAAGAC) and EF2 (GGARGTACCAGTSATCATGTT) [72] in a PCR reaction consisting of Taq reaction buffer (10 mM Tris- $\mathrm{HCl}, 50 \mathrm{mM} \mathrm{KCl}, 1.5 \mathrm{mM} \mathrm{MgCl}_{2}, \mathrm{pH} 8.3$ at $\left.25^{\circ} \mathrm{C}\right), 100 \mu \mathrm{M}$ of each deoxyribonucleoside triphosphate, 
$0.3 \mu \mathrm{M}$ of each primer, $0.62 \mathrm{U}$ HotStart-polymerase (NEB) and $1 \mu \mathrm{L}$ template DNA solution. The final $\mathrm{MgCl}_{2}$ concentration was adjusted to $2 \mathrm{mM}$. The PCR cycling conditions for the amplification of tef1 $\alpha$ included an initial denaturation for $30 \mathrm{~s}$ at $95^{\circ} \mathrm{C} ; 30$ cycles consisting of $30 \mathrm{~s}$ at $94{ }^{\circ} \mathrm{C}, 30 \mathrm{~s}$ at $58^{\circ} \mathrm{C}$, and $1 \mathrm{~min}$ at $68^{\circ} \mathrm{C}$; and final extension for $5 \mathrm{~min}$ at $68^{\circ} \mathrm{C}$. Fusarium species were identified by multiple alignment of each sequence with the sequences of standard strains and other reference sequences using ClustalW [73] in MEGA version 7.0.2 [74].

\subsection{Meteorological and Agronomical Data}

The meteorological data were obtained from the closest weather stations $(<10 \mathrm{~km})$ to the sample location. In Bavaria, meteorological data were received from AgrarMeterologie of the Bavarian state research center for agriculture (https://www.wetter-by.de). The air temperature and the relative air humidity were recorded as daily means and precipitation as monthly sum from May to September. The agronomical field data of tillage and previous crop were obtained from breeding companies and farmers. The previous crop was assigned to four categories, in maize (silage maize and grain maize), wheat (winter wheat), sugar beet and other crops (potato, cabbage, strawberry, rye, barley). Soil tillage was differentiated into two groups; ploughing (moldboard ploughing) and no ploughing or reduced tillage including chisel ploughing and rotary harrow.

\subsection{Statistical Analyses}

Statistical analyses were performed using Statistica version 13.3 (TIBCO ${ }^{\circledR}$ Data Science, Palo Alto, CA, USA). Non-parametric data of average infection, tillage treatments and previous crop were statistically analyzed using Mann-Whitney-U-Test and Kruskal-Wallis-ANOVA. Tests were performed at a probability level of 95\%. Pearson's correlation coefficients were used to examine the relationship between temperature and precipitation in June, July, August, and September and infection with predominant Fusarium species occurring on ear and stalk samples. In addition, a multiple regression was performed to determine the relationship of ear and stalk infection with temperature and/ precipitation in July for each sample location. The impact of weather conditions, soil tillage or pre-crops on the occurrence of Fusarium species was analyzed by variance components derived from the overall variance estimated with the restricted maximum likelihood model.

Supplementary Materials: The following are available online at http://www.mdpi.com/2076-0817/9/3/236/s1, Table S1: Mean monthly air temperature $\left[{ }^{\circ} \mathrm{C}\right](\mathrm{AT})$, mean relative humidity [\%] (RH) and cumulative monthly precipitation [mm] (PP) in June, July, August and September in the year 2016, 2017 and 2018 within the sampling locations.

Author Contributions: Conceptualization, A.P.; methodology, A.P., S.S. and L.R.R.; validation, A.P., L.R.R. and S.S.; formal analysis, A.P.; investigation, A.P. and L.R.R.; resources, A.P., S.S. and L.R.R.; data curation, A.P.; writing—original draft preparation; A.P.; writing—review and editing, A.v.T., P.K., S.S., L.R.R.; visualization, A.P.; supervision, A.v.T.; project administration, A.v.T. and P.K.; funding acquisition, A.v.T. and P.K. All authors have read and agreed to the published version of the manuscript.

Funding: This research was funded by Federal Ministry of Food and Agriculture, Germany grant number 2818208315.

Acknowledgments: We thank Bettina Kessel (KWS SAAT), Christoph Mainka (Syngenta), Holger Scheffczyk (Limagrain) and Steffen Wesemann (Bayer Crop Sciences) for collection of infected maize material. We also appreciated the excellent technical assistance by Brigitte Jünemann.

Conflicts of Interest: The authors declare no conflict of interest.

\section{References}

1. Munkvold, G.P.; McGee, D.C.; Carlton, W.M. Importance of different pathways for maize kernel infection by Fusarium moniliforme. Phytopathology 1997, 87, 209-217. [CrossRef]

2. Reid, L.M.; Nicol, R.W.; Ouellet, T.; Savard, M.; Miller, J.D.; Young, J.C.; Stewart, D.W.; Schaafsma, A.W. Interaction of Fusarium graminearum and F. moniliforme in maize ears: Disease progress, fungal biomass, and mycotoxin accumulation. Phytopathology 1999, 89, 1028-1037. [CrossRef] [PubMed] 
3. Christensen, J.J.; Wilcoxsen, R.D. Stalk Rot of Corn; The American Phytopathological Society: Worcester, MA, USA, 1966.

4. IARC. International Ageny of Research on Cancer: Fumonsisin B1 (Group 2B), Summary of Data Reported and Evaluation. Int. Peer Rev. Chem. Saf. Inf. 2002, 82, 301-309.

5. Desjardins, A.E.; Maragos, C.M.; Proctor, R.H. Maize ear rot and moniliformin contamination by cryptic species of Fusarium subglutinans. J. Agric. Food Chem. 2006, 54, 7383-7390. [CrossRef] [PubMed]

6. Logrieco, A.; Bailey, J.A.; Corazza, L.; Cooke, B.M. Mycotoxins in Plant Disease; Springer: Dordrecht, The Netherlands, 2002.

7. Alshannaq, A.; Yu, J.-H. Occurrence, toxicity, and analysis of major mycotoxins in food. Int. J. Environ. Res. Public Health 2017, 14, 632. [CrossRef] [PubMed]

8. Arino, A.A.; Bullermann, L.B. Fungal colonization of corn grown in Nebraska in relation to year, genotype and growing conditions. J. Food Prot. 1994, 57, 1084-1087. [CrossRef] [PubMed]

9. Mansfield, M.A.; Wolf, E.D.d.; Kuldau, G.A. Relationships between weather conditions, agronomic practices, and fermentation characteristics with deoxynivalenol content in fresh and ensiled maize. Plant Dis. 2005, 89, 1151-1157. [CrossRef]

10. Flett, B.C.; McLaren, N.W.; Wehner, F.C. Incidence of ear rot pathogens under alternating corn tillage practices. Plant Dis. 1998, 82, 781-784. [CrossRef]

11. Scala, V.; Aureli, G.; Cesarano, G.; Incerti, G.; Fenelli, C.; Scala, F.; Reverberi, M.; Bonanomi, G. Climate, soil management, and cultivar affect Fusarium head blight incidence and deoxynivalenol accumulation in durum wheat of southern Italy. Frontiers 2016, 7, 1014. [CrossRef]

12. Fernandes, M.R.; Huber, D.; Basnyat, P.; Zentner, R.P. Impact of agronomic practices on populations of Fusarium and other fungi in cereal and noncereal crop residues on the Canadian Prairies. Soil Tillage Res. 2008, 100, 60-71. [CrossRef]

13. Edwards, S.; Jennings, P. Impact of agronomic factors on Fusarium mycotoxins in harvested wheat. Food Addit. Contam. Part A 2018, 35, 2443-2454. [CrossRef] [PubMed]

14. Munkvold, G.P.; Hellmich, R.L.; Showers, W.B. Reduced Fusarium ear rot and symptomless infection in kernels of maize genetically engineered for European corn borer resistance. Phytopathology 1997, 87, 1071-1077. [CrossRef] [PubMed]

15. Schaafsma, A.W.; Hooker, D.C.; Baute, T.S.; Illincic-Tamburic, L. Effect of Bt-corn hybrids on deoxynivalenol content in grain at harvest. Am. Phytopathol. Soc. 2002, 86, 1123-1126.

16. Sobeck, E.A.; Munkvold, G.P. European corn borer (Lepidoptera: Pyralidae) larvae as vectors of Fusarium moniliforme, causing kernel rot and symptomless infection of maize kernels. J. Econ. Entomol. 1999, 92, 503-509. [CrossRef]

17. Reid, L.M.; Hamilton, R.l. Effects of inoculation position, timing, macroconidial concentration, and irrigation on resistance of maize to Fusarium graminearum infection through kernels. Can. J. Plant Pathol. 1996, 18, 279-285. [CrossRef]

18. Reid, L.M.; Bolton, A.T.; Hamilton, R.I.; Woldemariam, T.; Mather, D.E. Effect of silk age on resistance of maize to Fusarium graminearum. Can. J. Plant Pathol. 1992, 14, 293-298. [CrossRef]

19. Windels, C.E. Late-season colonization and survival of Fusarium graminearum group II in cornstalks in Minnesota. Plant Dis. 1984, 68, 791-798. [CrossRef]

20. Kommedahl, T.; Windels, C.E.; Stucker, R.E. Occurrence of Fusarium species in root and stalks of symptomless corn plants during the growing season. Phytopathology 1979, 69, 961-966. [CrossRef]

21. Dodd, J.L. The role of plant stresses in development of corn stalk rots. Plant Dis. 1980, 64, 533-535. [CrossRef]

22. Bottalico, A. Fusarium diseases of cereals: Species complex and related mycotoxin profiles in Europe. J. Plant Pathol. 1998, 80, 85-103.

23. Munkvold, G.P. Epidemiology of Fusarium diseases and their mycotoxins in maize ears. Eur. J. Plant Pathol. 2003, 109, 705-713. [CrossRef]

24. Dill-Macky, R.; Jones, R.K. The effect of previous crop residues and tillage on Fusarium head blight of wheat. Plant Dis. 2000, 84, 71-76. [CrossRef] [PubMed]

25. Sutton, J.C. Epidemiology of wheat head blight and maize ear rot caused by Fusarium graminearum. Can. J. Plant Pathol. 1982, 4, 195-209. [CrossRef] 
26. Cotten, T.K.; Munkvold, G.P. Survival of Fusarium moniliforme, F. proliferatum, and F. subglutinans in maize stalk residue. Phytopathology 1998, 88, 550-555. [CrossRef]

27. Flett, B.C.; Wehner, F.C. Incidence of Stenocarpella and Fusarium cob rots in monoculture maize under different tillage systems. J. Phytopathol. 1991, 133, 327-333. [CrossRef]

28. Parker, D.T.; Burrows, W.C. Root and stalk rot in corn as affected by fertilizer and tillage treatment. Agron 1959, 51, 414-417. [CrossRef]

29. Schlüter, K.; Kropf, U. Fusarium-Befall aus Dem Boden? Infektionswege von Fusarien. Landwirtschaft ohne Pflug, February 2006; 28-33.

30. Skoglund, L.G.; Brown, W.M. Effects of tillage regimes and herbicides on Fusarium species associated with corn stalk rot. Can. J. Plant Pathol. 1988, 10, 332-338. [CrossRef]

31. Steinkellner, S.; Shala-Mayrhofer, V.; Langer, I. Influence of tillage on Fusarium spp. in different crop rotation systems. Mycotoxin Res. 2002, 18, 11-15. [CrossRef]

32. Khonga, E.B.; Sutton, J.C. Inoculum production and survival of Gibberella zeae in maize and wheat residues. Can. J. Plant Pathol. 1988, 10, 232-239. [CrossRef]

33. Juroszek, P.; Von Tiedemann, A. Climatic changes and the potential future importance of maize diseases: A short review. J. Plant Dis. Prot. 2013, 120, 49-56. [CrossRef]

34. Dorn, B.; Forrer, H.-R.; Schürch, S.; Vogelgsang, S. Fusarium species complex on maize in Switzerland: Occurrence, prevalence, impact and mycotoxins in commercial hybrids under natural infection. Eur. J. Plant Pathol. 2009, 125, 51-61. [CrossRef]

35. Bottalico, A.; Perrone, G. Toxigenic Fusarium species and mycotoxins associated with head blight in small-grain cereals in Europe. Eur. J. Plant Pathol. 2002, 108, 611-624. [CrossRef]

36. Logrieco, A.; Mul, G.; Moretti, A.; Bottalico, A. Toxigenic Fusarium species and mycotoxins associated with maize ear rot in Europe. Eur. J. Plant Pathol. 2002, 108, 597-609. [CrossRef]

37. Booth, C. The Genus Fusarium; Commonwealth Mycological Institute: Kew, UK, 1971; ISBN 0851980465.

38. Marín, S.; Sanchis, V.; Magan, N. Water activity, temperature, and pH effects on growth of Fusarium moniliforme and Fusarium proliferatum isolates from maize. Can. J. Microbiol. 1995, 41, 1063-1070. [CrossRef] [PubMed]

39. Shelby, R.A.; White, D.G.; Bauske, E.M. Different fumonsin production in maize hybrids. Plant Dis. 1994, 78, 582-584. [CrossRef]

40. Miller, J.D. Factors that affect the occurrence of fumonisin. Environ. Health Perspect. 2001, 109, 321-324. [PubMed]

41. De-Wolf, E.D.; Madden, L.V.; Lipps, P.E. Risk assessment models for wheat Fusarium head blight epidemics based on within-season weather data. Phytopathology 2002, 93, 428-435. [CrossRef]

42. Munkvold, G.P. Cultural and genetic approaches to managing mycotoxins in maize. Annu. Rev. Phytopathol. 2003, 41, 99-116. [CrossRef]

43. Stewart, D.W.; Reid, L.M.; Nicol, R.W.; Schaafsma, A.W. A mathematical simulation of growth of Fusarium in maize ears after artificial inoculation. Phytopathology 2002, 92, 534-541. [CrossRef]

44. Murillo-Williams, A.; Munkvold, G.P. Systemic infection by Fusarium verticillioides in maize plants grown under three temperature regimes. Plant Dis. 2008, 92, 1695-1700. [CrossRef]

45. Gai, X.; Dong, H.; Wang, S.; Liu, B.; Zhang, Z.; Li, X.; Gao, Z. Infection cycle of maize stalk rot and ear rot caused by Fusarium verticillioides. PLoS ONE 2018, 13, e0201588. [CrossRef] [PubMed]

46. Desai, S.; Hedge, R. Identification of suitable method and time for artificial inoculation of maize with stalk rotting fungi. Indien Phytopathol. 1992, 45, 381-382.

47. Scauflaire, J.; Gourgue, M.; Munaut, F. Fusarium temperatum sp. nov. from maize, an emergent species closely related to Fusarium subglutinans. Mycologia 2011, 103, 586-597. [CrossRef] [PubMed]

48. Czembor, E.; Stępień, Ł.; Waśkiewicz, A. Effect of environmental factors on Fusarium species and associated mycotoxins in maize grain grown in Poland. PLoS ONE 2015, 10, e013364. [CrossRef] [PubMed]

49. Boutigny, A.-L.; Scauflaire, J.; Ballois, N.; Ioos, R. Fusarium temperatum isolated from maize in France. Eur. J. Plant Pathol. 2017, 148, 997-1001. [CrossRef]

50. Venturini, G.; Toffolatti, S.L.; Passera, A.; Pilu, R.; Quaglino, F.; Casati, P. First report of Fusarium temperatum causing ear rot on maize in Italy: Disease note. J. Plant Pathol. 2016, 98, 677-697. 
51. Lanza, F.E.; Mayfield, D.A.; Munkvold, G.P. First report of Fusarium temperatum causing maize seedling blight and seed rot in North America. Plant Dis. 2016, 100, 1019-1024. [CrossRef]

52. Shin, J.-H.; Han, J.-H.; Lee, J.K.; Kim, K.S. Characterization of the maize stalk rot pathogens Fusarium subglutinans and F. temperatum and the effect of fungicides on their mycelial growth and colony formation. Plant Pathol. J. 2014, 30, 397-406. [CrossRef]

53. Wang, J.-H.; Zhang, J.-B.; Li, H.-P.; Gong, A.-D.; Xue, S.; Agboola, R.S.; Liao, Y.-C. Molecular identification, mycotoxin production and comparative pathogenicity of Fusarium temperatum isolated from maize in China. J. Phytopathol. 2014, 162, 147-157. [CrossRef]

54. Robles-Barrios, K.F.; Medina-Canales, M.G.; Rodríguez-Tovar, A.V.; Pérez, N.O. Morphological and molecular characterization, enzyme production and pathogenesis of Fusarium temperatum on corn in Mexico. Can. J. Plant Pathol. 2015, 37, 495-505. [CrossRef]

55. Fumero, M.V.; Reynoso, M.M.; Chulze, S. Fusarium temperatum and Fusarium subglutinans isolated from maize in Argentina. Int. J. Food Microbiol. 2015, 199, 86-92. [CrossRef] [PubMed]

56. Moretti, A.; Mulé, G.; Ritieni, A.; Láday, M.; Stubnya, V.; Hornok, L.; Logrieco, A. Cryptic subspecies and beauvericin production by Fusarium subglutinans from Europe. Int. J. Food Microbiol. 2008, 127, 312-315. [CrossRef] [PubMed]

57. Schaafsma, A.W.; Tamburic-Ilincic, L.; Hooker, D.C. Effect of previous crop, tillage, field size, adjacent crop, and sampling direction on airborne propagules of Gibberella zeae/Fusarium graminearum, Fusarium head blight severity and deoxynivalenol accumulation in winter wheat. Can. J. Plant Pathol. 2005, 27, 217-224. [CrossRef]

58. Gödecke, R. Einflussfaktoren der Mykotoxinbildung durch Ährenbefall mit Fusarium spp. in Verschiedenen Winterweizenfruchtfolgen. Ph.D. Thesis, University of Goettingen, Goettingen, Germany, 2010.

59. Parry, D.W.; Jenkinson, P.; McLeod, L. Fusarium ear blight (scab) in small grain cereals-A review. Plant Pathol. 1995, 44, 207-238. [CrossRef]

60. Nyvall, R.F.; Kommedahl, T. Saprophytism and survival of Fusarium moniliforme in corn stalks. Phytopathology 1970, 60, 1233-1235. [CrossRef]

61. Vasileiadis, V.P.; Sattin, M.; Otto, S.; Veres, A.; Pálinkás, Z.; Ban, R.; Pons, X.; Kudsk, P.; van der Weide, R.; Czembor, E.; et al. Crop protection in European maize-based cropping systems: Current practices and recommendations for innovative Integrated Pest Management. Agric. Syst. 2011, 104, 533-540. [CrossRef]

62. Steinkellner, S.; Langer, I. Impact of tillage on the incidence of Fusarium spp. in soil. Plant Soil 2004, 267, 13-22. [CrossRef]

63. Parr, J.F.; Papendick, R.I. Factors affecting the decomposition of crop residues by microorganisms. Crop Residue Manag. Syst. 1978, 31, 1001-1129.

64. Pereyra, S.A.; Dill-Macky, R.; Sims, A.L. Survival and inoculum production of Gibberella zeae in wheat residue. Plant Dis. 2004, 88, 724-730. [CrossRef]

65. Byrnes, K.; Carroll, R.B. Fungi causing stalk rot of conventional-tillage and no-tillage corn in Delaware. Plant Dis. 1986, 70, 238-239. [CrossRef]

66. Sutton, J.C.; Baliko, W.; Funnell, H.S. Relation of weather variables to incidence of zearalenone in corn in southern Ontario. Can. J. Plant Sci. 1980, 60, 149-155. [CrossRef]

67. Lori, G.A.; Sisterna, M.N.; Sarandón, S.J.; Rizzo, I.; Chidichimo, H. Fusarium head blight in wheat: Impact of tillage and other agronomic practices under natural infection. Crop Prot. 2009, 28, 495-502. [CrossRef]

68. Kurtz, B.; Karlovsky, P.; Vidal, S. Interaction between western corn rootworm (Coleoptera chrysomelidae) larvae and root-infecting Fusarium verticillioides. Environ. Entomol. 2010, 39, 1532-1538. [CrossRef] [PubMed]

69. EPPO. PP 1/285. PP 1/285 (1): Fursarium Ear Rot of Maize; European and Mediterranean Plant Protection Organisation (EPPO): Paris, France, 2015; Volume 45, pp. 336-339.

70. Leslie, J.F.; Summerell, B.A. The Fusarium Laboratory Manual; Blackwell Publishing: Hoboken, NJ, USA, 2006.

71. Brandfass, C.; Karlovsky, P. Upscaled CTAB-based DNA extraction and real-time PCR assays for Fusarium culmorum and F. graminearum DNA in plant material with reduced sampling error. Int. J. Mol. Sci. 2008, 9, 2306-2321. [CrossRef] [PubMed]

72. O'Donnell, K.; Cigelnik, E.; Nirenberg, H.I. Molecular systematics and phylogeography of the Gibberella fujikuroi species complex. Mycologia 1998, 90, 465-469. [CrossRef] 
73. Thompson, J.D.; Higgins, D.G.; Gibson, T.J. CLUSTAL W: Improving the sensitivity of progressive multiple sequence alignment through sequence weighting, position-specific gap penalties and weight matrix choice. Nucleic Acid Res. 1994, 22, 4673-4680. [CrossRef]

74. Kumar, S.; Stecher, G.; Tamura, K. MEGA7: Molecular evolutionary genetics analysis version 7.0 for bigger datasets. Mol. Biololgie Evol. 2016, 33, 1870-1874. [CrossRef] 